\title{
Carboxyfluoresce in Dye Uptake to Measure Connexin-mediated Hemichannel Activity in Cultured Cells
}

Joe A. Potter, Gareth W. Price, Chelsy L. Cliff, Bethany M. Williams,

Claire E. Hills and Paul E. Squires*

Joseph Banks Laboratories, School of Life Sciences, University of Lincoln, Lincoln, United Kingdom *For correspondence: psquires@lincoln.ac.uk

[Abstract] Connexins are membrane bound proteins that facilitate direct and local paracrine mediated cell-to-cell communication through their ability to oligomerise into hexameric hemichannels. When neighbouring channels align, they form gap-junctions that provide a direct route for information transfer between cells. In contrast to intact gap junctions, which typically open under physiological conditions, undocked hemichannels have a low open probability and mainly open in response to injury. Hemichannels permit the release of small molecules and ions (approximately $1 \mathrm{kDa}$ ) into the local intercellular environment, and excessive expression/activity has been linked to a number of disease conditions. Carboxyfluorescein dye uptake measures functional expression of hemichannels, where increased hemichannel activity/function reflects increased loading. The technique relies on the uptake of a membrane-impermeable fluorescent tracer through open hemichannels, and can be used to compare channel activity between cell monolayers cultured under different conditions, e.g. control versus disease. Other techniques, such as biotinylation and electrophysiology can measure cell surface expression and hemichannel open probability respectively, however, carboxyfluorescein uptake provides a simple, rapid and cost-effective method to determine hemichannel activity in vitro in multiple cell types.

\section{Graphic abstract:}

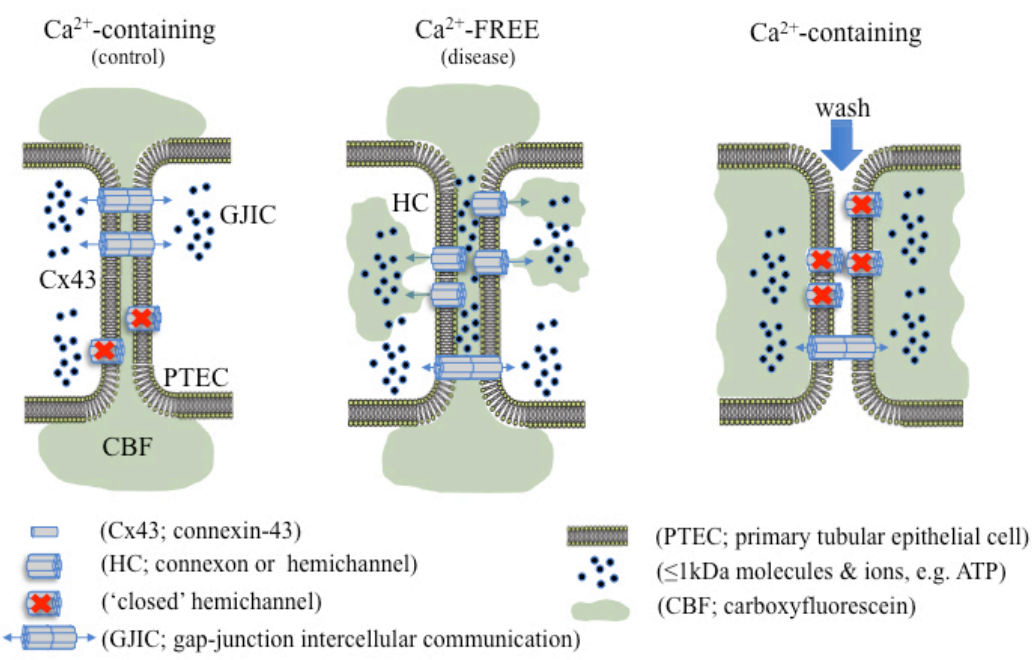

\section{Using dye uptake to measure hemichannel activity}


Keywords: Connexin, Hemichannels, Carboxyfluorescein, Dye uptake

[Background] Connexins (Cx) are integral transmembrane proteins that oligomerise into connexons at the cell surface. Connexons dock with similar hexameric protein complexes on adjacent cells to form a bidirectional conduit for gap junction intercellular communication (GJIC; Bosco et al., 2011). Gap junctions play an important role in synchronizing cellular activity and allow for the direct exchange of small ions, metabolites and secondary messengers, crucial for cellular function, survival and tissue homeostasis (Spray and Hanani, 2019). Under normal conditions, undocked connexons, known as hemichannels, remain mostly closed; however, in a pathophysiological context hemichannel-mediated intercellular communication can predominate, permitting the release of 1-2 $\mathrm{kDa}$ molecules, including adenosine triphosphate (ATP) into the extracellular milieu (Solini et al., 2015; Hills et al., 2018; Taruno, 2018; Siamantouras et al., 2019). Altered hemichannel activity has previously been linked to inflammation, fibrosis and the progression of various disease states (Roy et al., 2017; Hills et al., 2018; Cea et al., 2020; Sáez et al., 2020). Consequently, quantitative characterisation of hemichannel activity can inform on the onset and progression of disease, e.g., chronic kidney disease (CKD), along with highlighting potential targets for therapeutic intervention (Price et al., 2020).

Depending on the constituent connexin isoform, several factors are known to open hemichannels, including temperature, $\mathrm{pH}$, enteric pathogenic infections and low extracellular calcium ([Ca $\left.{ }^{2+}\right]_{\mathrm{e}}$ ) (Trexler et al., 1999; Ceelen et al., 2011; Lopez et al., 2016; Pinto et al., 2017). Whilst various methods can determine expression and localisation of connexin hemichannel subunits at the cell surface, e.g., biotinylation combined with immunoblot analysis and immunocytochemistry respectively, these do not provide a measure for functional changes in connexin-mediated cell communication. In recent years, a range of different methods have been used to evaluate the functional implications of altered hemichannel activity and/or function (Johnson et al., 2016). One of these techniques involves electrophysiological characterisation using whole-cell patch clamp recordings. Although dual whole-cell voltage recordings offer a highly attractive method to attain vast amounts of information on hemichannel permeability selectivity, opening/closing kinetics, open probability latency and presence of subconductance states, it is not without its drawbacks (Brokamp et al., 2012). Not only is this technique highly complex, the membrane potential needed to gate hemichannels is cell-type specific, a difficult hurdle to overcome (Veenstra, 2001). Quantification of hemichannel-permeable molecules into the local extracellular environment (e.g., ATP release) via luminescence based assays is much simpler, yet provides minimal, indirect information with regards to hemichannel activity and would benefit from the use of potentially costly general or local connexin inhibitors (Musil and Goodenough, 1991; Brokamp et al., 2012; Sáez and Green, 2018; Price et al., 2020). Although these techniques provide excellent methodological approaches for identifying cell-surface connexin expression and hemichannel open probability, it is the use of simpler hemichannel-permeable, membrane impermeant dye uptake studies that are routinely used (Johnson et al., 2016). Dye uptake studies make use of controlled parameters and utilise altered $\left[\mathrm{Ca}^{2+}\right]_{\mathrm{e}}$ to gate hemichannels, providing a simple, efficient and reliable procedure. Several fluorescent tracers, including Lucifer Yellow, ethidium bromide, 4',6-diamidino-2-phenylindole 
(DAPI), propidium iodide (PI), and 5(6)-carboxyfluorescein can be used to quantify hemichannel activity, with the extent of dye uptake proportional to the number of active cell-surface hemichannels (Lopez et al., 2016). Unfortunately, the majority of these tracers are hazardous and carcinogenic and require careful handling; however, this step-by-step protocol utilises the non-hazardous, 376 Da polyanionic fluorescent probe, 5(6)-carboxyfluorescein, to quantitively measure hemichannel activity in proximal tubular epithelial cells in vitro.

\section{Materials and Reagents}

1. $50 \mathrm{ml}$ Falcon tubes

2. Fluorodish, $35 \mathrm{~mm}$ (World Precision Instruments, catalog number: FD35-100)

3. Pasteur pipette, $4 \mathrm{ml}$ (Sigma-Aldrich, catalog number: BR747770)

4. Clonal human kidney proximal tubule (HK-2) epithelial cell line (American Type Culture Collection, catalog number: CRL-2190)

5. Dulbecco's Modified Eagle Medium/Ham's F-12 (Fisher Scientific, catalog number: 31331093)

6. Dulbecco's Modified Eagle Medium (Fisher Scientific, catalog number: 11966025)

7. Ham's F-12 (Fisher Scientific, catalog number: 31-765-035)

8. Penicillin (100 IU/ml)-streptomycin (100 $\mathrm{\mu g} / \mathrm{ml})$ (Sigma-Aldrich, catalog number: P4458-100mL)

9. Epidermal growth factor $(5 \mathrm{ng} / \mathrm{ml}$ ) (Sigma-Aldrich, catalog number: E9644-.5mg)

10. Transforming Growth Factor-beta1 (TGF- $\beta 1$ ), stored at $-20^{\circ} \mathrm{C}$ (Sigma-Aldrich, catalog number: T1654)

11. Foetal calf serum (Fisher Scientific, catalog number: 10500064)

12. Sodium chloride ( $\mathrm{NaCl}$ ) (Fisher scientific, catalog number: $\mathrm{S} / 3160 / 65)$

13. Potassium chloride (KCl) (Sigma-Aldrich, catalog number: P3911)

14. Magnesium sulphate heptahydrate $\left(\mathrm{MgSO}_{4} \cdot 7 \mathrm{H}_{2} \mathrm{O}\right)$ (Sigma-Aldrich, catalog number: 230391)

15. Sodium phosphate dibasic dihydrate $\left(\mathrm{Na}_{2} \mathrm{HPO}_{4} \cdot 2 \mathrm{H}_{2} \mathrm{O}\right)$ (Sigma-Aldrich, catalog number: 71643 )

16. Potassium dihydrogen phosphate $\left(\mathrm{KH}_{2} \mathrm{PO}_{4}\right)$ (Sigma-Aldrich, catalog number: 1.04873)

17. Sodium bicarbonate $\left(\mathrm{NaHCO}_{3}\right)$ (Sigma-Aldrich, catalog number: S5761)

18. HEPES (4-(2-hydroxyethyl)-1-piperazineethanesulfonic acid) (Sigma-Aldrich, catalog number: H3375)

19. Calcium chloride dihydrate $\left(\mathrm{CaCl}_{2} \cdot 2 \mathrm{H}_{2} \mathrm{O}\right)$ (Sigma-Aldrich, catalog number: 223506)

20. D-glucose $\left(\mathrm{C}_{6} \mathrm{H}_{12} \mathrm{O}_{6}\right)$ (Sigma-Aldrich, catalog number: G8270)

21. Sodium hydroxide $(\mathrm{NaOH})$ (Sigma-Aldrich, catalog number: $\mathrm{S} 8045)$

22. Hydrochloric acid ( $\mathrm{HCl})$ (Sigma-Aldrich, catalog number: 320331)

23. EGTA (ethylene glycol-bis( $\beta$-aminoethyl ether)-N,N,N',N'-tetraacetic acid) (Sigma-Aldrich, catalog number: E3889)

24. Cell culture
a. Growth culture medium, stored at $4{ }^{\circ} \mathrm{C}$ (see Recipes)
b. Low $(5 \mathrm{mM})$ glucose medium, stored at $4{ }^{\circ} \mathrm{C}$ (see Recipes) 
c. Low $(5 \mathrm{mM})$ glucose serum free medium, stored at $4{ }^{\circ} \mathrm{C}$ (see Recipes)

25. 5(6)-Carboxyfluorescein, stored at RT (Sigma-Aldrich, catalog number: 21879) (see Recipes)

26. $1 \times$ Calcium-containing balanced salt solution, stored at $4{ }^{\circ} \mathrm{C}$ (see Recipes)

27. $1 \times$ Calcium-free balanced salt solution, stored at $4{ }^{\circ} \mathrm{C}$ (see Recipes)

\section{Equipment}

1. Small, unstirred, heated water bath $\left(37^{\circ} \mathrm{C}\right)$ (Grant instruments Ltd, catalog number: 600142003 )

2. Clifton $14 \mathrm{~L}$, heated water bath $\left(37^{\circ} \mathrm{C}\right)$ (Nickel-electro Ltd, catalog number: NE1-14)

3. Humidified incubator: $37^{\circ} \mathrm{C}, \mathrm{pH} 7.4,5 \% \mathrm{CO}_{2}\left(\mathrm{CO}_{2}\right.$ incubator, Panasonic, catalog number: $\mathrm{MCO}-$ 170AICD)

4. Linus photonics metafluor imaging workbench (Technical Manufacturing Corporation, catalog number: 63-530)

5. Photometrics CoolSNAP HQ CCD monochrome camera with power supply (Roper Scientific, catalog number: A01C881022)

6. Zeiss Axiovert 200 research inverted fluorescence microscope with heated stage (Carl Zeiss Ltd, catalog number: B40-080)

7. Zeiss $\mathrm{XBO} 75$ microscope lamp housing with EBX 75 isolated power supply (Carl Zeiss Ltd, catalog number: B40-065)

8. Lambda 10-2 optical filter changer (Sutter Instrument, catalog number: LB10-2)

9. Tempcontrol 37 (Carl Zeiss Ltd, catalog number: 37-2)

10. Dell precision PC (Dell, catalog number: T3500)

11. Liyama prolite PC monitor (liyama, catalog number: E2472HD)

12. Sonomatic sonicator (Jencon scientific Ltd, catalog number: E0375)

\section{Software}

$\begin{array}{llll}\text { 1. } & \text { Metamorph } & \text { v7.7.5.0 } & \text { software }\end{array}$ https://www.moleculardevices.com/products/cellular-imaging-systems/acquisition-andanalysis-software/metamorph-microscopy\#gref) (Meta imaging series by Molecular Devices Inc)

2. Fiji (ImageJ) v2.1.0 software (available from https://fiji.sc/) (ImageJ studio Ltd)

\section{Procedure}

A. Tissue culture

1. Maintain HK-2 cells (passages 18-30) in DMEM/F-12-containing FCS, EGF and penicillinstreptomycin growth media, which has a high basal glucose concentration (17.5 mM) to encourage cell growth. 
2. Seed HK-2 cells on sterile $35 \mathrm{~mm}$ fluorodishes at a seeding density of $1 \times 10^{4}$ in $2 \mathrm{ml} \mathrm{DMEM} / \mathrm{F}-$ 12-containing FCS, EGF and penicillin-streptomycin growth media (see Note 1).

3. Prior to treatment, culture HK-2 cells in low $(5 \mathrm{mM})$ glucose DMEM/F-12-containing FCS, EGF and penicillin-streptomycin medium for a period of $48 \mathrm{~h}$, followed by an overnight incubation in serum free low $(5 \mathrm{mM})$ glucose DMEM/F-12-containing EGF and penicillin-streptomycin medium to negate any pre-stimulatory effects from the high $(17.5 \mathrm{mM})$ glucose.

4. After overnight incubation in serum free low $(5 \mathrm{mM})$ glucose DMEM/F-12-containing EGF and penicillin-streptomycin media, treat HK-2 cells with a desired stimulus (e.g., TGF- $\beta 1,10 \mathrm{ng} / \mathrm{ml}$ ) against control HK-2 cells in serum free low (5 mM) glucose DMEM/F-12-containing EGF and penicillin-streptomycin media for $48 \mathrm{~h}$ with a final confluence of $80 \%$.

B. Balanced salt solutions and 5(6)-carboxyfluorescein preparation

1. Prepare $1 \mathrm{~L} 1 \times$ calcium-containing and $1 \mathrm{~L} 1 \times$ calcium-free balanced salt solution (see Recipes) and keep warm at $37^{\circ} \mathrm{C}$ in the small water bath.

2. Prepare two adequate carboxyfluorescein solutions $(200 \mu \mathrm{M})$ in $50 \mathrm{ml}$ Falcon tubes (see Note 2). One in $50 \mathrm{ml} 1 \times$ calcium-containing balanced salt solution and one in $50 \mathrm{ml} 1 \times$ calcium-free balanced salt solution (see Note 3 ). Sonicate both solutions at $44 \mathrm{kHz}$ for $10-20 \min \left(37^{\circ} \mathrm{C}\right.$ ) until the carboxyfluorescein powder has fully dissolved. Leave the solutions at $37^{\circ} \mathrm{C}$ in the water bath and use as needed.

C. Initial rig preparation

As seen in Figure 1, and in this order:

1. Switch on EBX 75 isolated lamp.

2. Switch on tempcontrol 37 , adjust the setpoint to $37^{\circ} \mathrm{C}$ (real). Allow $20-30 \mathrm{~min}$ for the heated stage to reach the desired temperature.

3. Switch on the CooISNAP HQ CCD monochrome camera.

4. Switch on Lambda 10-2 optical filter change, ensure light emission at $510 \mathrm{~nm}$ on the Axiovert 200 inverted microscope (see Note 4).

5. Remove cover and switch on microscope.

6. Switch on PC, load Metamorph and press 'acquire' from the acquire tab at the top of the screen. 


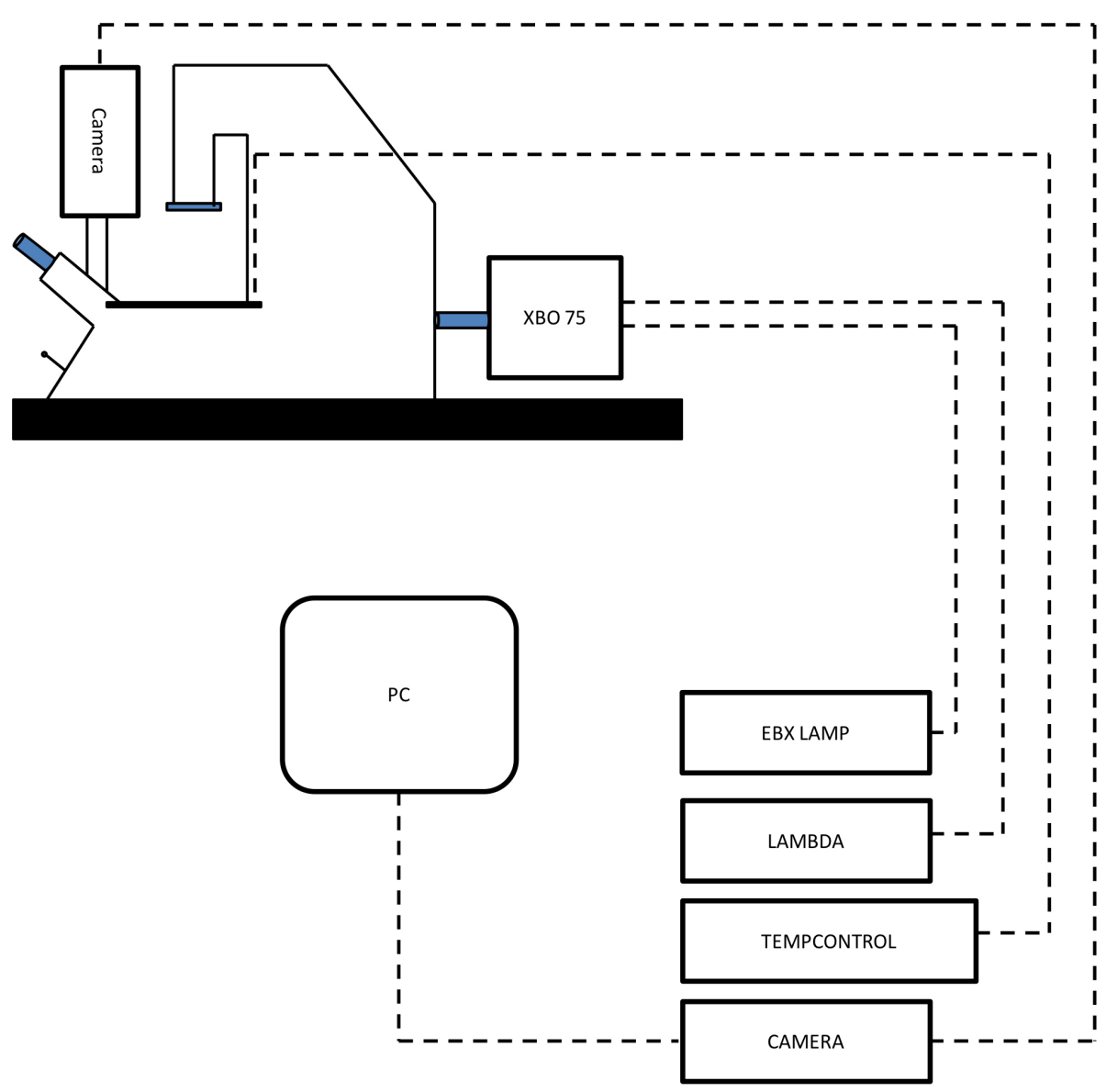

Figure 1. Axiovert inverted fluorescent microscope rig. A schematic of the inverted fluorescent microscope setup for carboxyfluorescein dye uptake assessment. Mounted on an anti-vibration Metafluor imaging workbench, the inverted fluorescent microscope has an XBO 75 microscope lamp connected to an EBX 75 isolated housing unit, along with a Lambda 10-2 optical filter changer. A heated stage is also fitted and controlled by a tempcontrol 37 unit. Located at the front of the microscope, a cooISNAP HQ CCD monochrome camera is mounted, linked to a power supply and subsequently connected to a PC for image visualisation.

D. Carboxyfluorescein dye uptake

1. Remove one fluorodish from the humidified incubator and aspirate the media using a Pasteur pipette into a waste pot.

2. To permit hemichannel dye uptake, incubate cells in $2 \mathrm{ml} 1 \times$ calcium-free carboxyfluorescein solution at $37^{\circ} \mathrm{C}$ in a humidified incubator for $10 \mathrm{~min}$ (see Note 5).

3. To close the hemichannels, using a Pasteur pipette, remove the $1 \times$ calcium-free carboxyfluorescein solution and replace with $2 \mathrm{ml} 1 \times$ calcium-containing carboxyfluorescein solution at $37^{\circ} \mathrm{C}$ in a humidified incubator for $5 \mathrm{~min}$.

4. To remove any residual carboxyfluorescein dye which may interfere with imaging, wash cells carefully using $20 \mathrm{ml}$ pre-warmed $1 \times$ calcium-containing balanced salt solution leaving 1-2 ml of $1 \times$ calcium-containing balanced salt solution in the fluorodish (see Note 6). 


\section{E. Image capture}

1. Ensure image capture is completed in a dark environment. To standardise image capture, cells producing the brightest signal (TGF- $\beta 1$ treated cells) are measured first and exposure opening time is fixed for comparison between treatments.

2. To fix the exposure time, initially place the cells on the microscope heated stage, turn on the fluorescence (emitted light captured at $510 \mathrm{~nm}$ ) and set the slider switch to the lens (eye symbol) on the microscope (see Note 7).

3. Locate a cell population producing a bright image, switch the microscope slider to the camera (camera symbol), and using the acquire window in Metamorph, press 'F2: Show Live' to visualise cells on the PC screen. Adjust the focus of the image and press 'AutoExpose' (Figure 2) (see Note 8).

4. Once the exposure time is set, to reduce photobleaching, set the slider switch back to the lens and efficiently move the fluorodish to locate another isolated cell population for image capture. After this time, set the slider switch to the camera and in Metamorph, press 'F2: Show Live', adjust the focus of the image and finally press the 'Acquire' button to capture the image (Figure 2) (see Note 9).

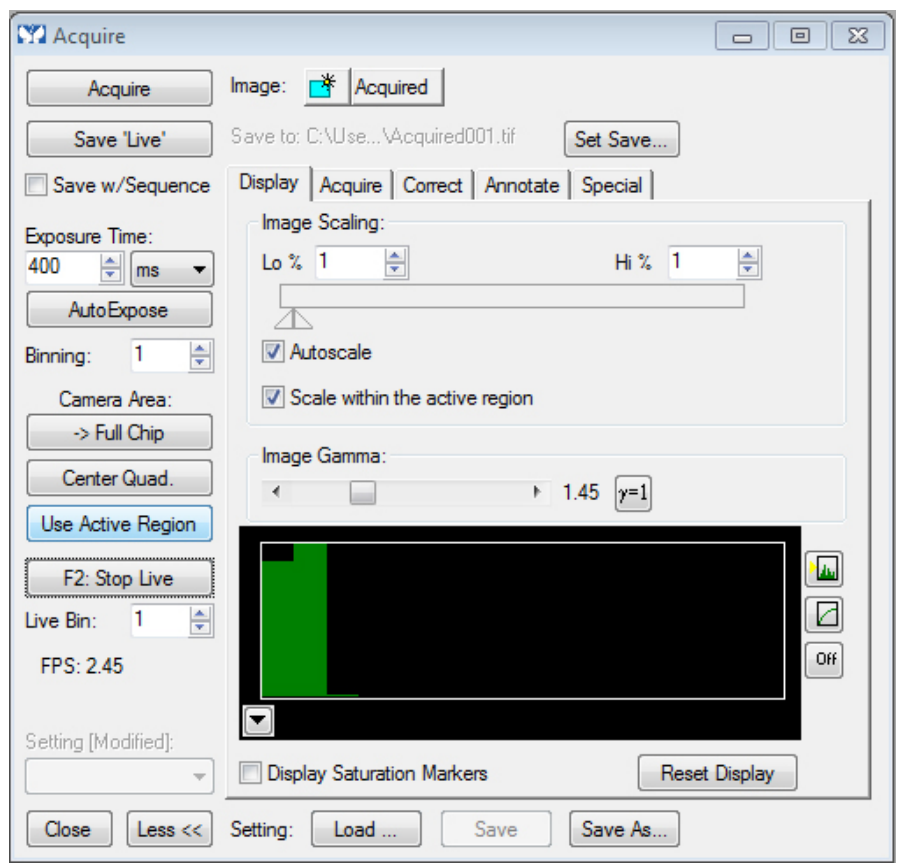

Figure 2. A representation of the 'Acquire' tab in Metamorph V.7.7.5.0. A screenshot of the 'Acquire' window to understand the different functions is shown. In order to visualise the cell image on the PC screen, 'F2: Show Live'/'F2: Stop Live' should be pressed, followed by either the 'AutoExpose' button or the 'Acquire' button to capture the live image.

5. Repeat the process until 10-15 images are captured (see Note 10).

6. To save the images in Metamorph, go to:

a. File (located top left of the screen). 
b. Setup Sequential File Names...

c. Set the 'Base Name' as the condition (i.e., TGF- $\beta 1$ ).

d. Set the Image Number starting from 1.

e. Set the number width to 1 .

f. Set the 'Save As Type' to 'Metamorph TIFF'.

g. Set 'If image already exists' to 'Skip to end of sequence'.

h. 'Select Directory' saves the files to a designated folder.

i. On the PC keyboard, use the 'Control+U' shortcut to complete this for each image.

7. Turn off the fluorescence, discard the fluorodish and repeat from Section $D$ (do not alter the exposure time for the remainder of the experiment).

\section{Data analysis}

The images are analysed using Fiji, an imaging processing software based on ImageJ. First, the images are batch converted into JPG files and enhanced. Each image is then individually processed to acquire cell intensity values which are averaged and statistically tested.

\section{A. Image Preparation}

1. Images are batch processed using a set of instructions called a macro, which achieve the following:

a. TIFF files are lossless (or uncompressed) images which are often difficult to handle, and so we batch convert them to JPG.

b. Fiji defaults to a grayscale colour lookup table, so this is changed to green.

c. The images often require enhancement (contrast etc.).

2. In the toolbar, click 'Process', 'Batch', and then 'Macro'. A box will appear (Figure 3)

3. Click 'Input' and select the folder of input images.

4. Create a new folder for the processed images, click 'Output', and select this new folder.

5. Under the 'Output format' list, select 'JPEG'.

6. In the big textbox in the centre of the window, type in the following (see Note 11):

run ("Green");

run("Enhance Local Contrast (CLAHE)", "blocksize=127 histogram=256 maximum $=3$ mask $=\star$ None*") ;

7. Click 'Process' to start the batch conversion. 


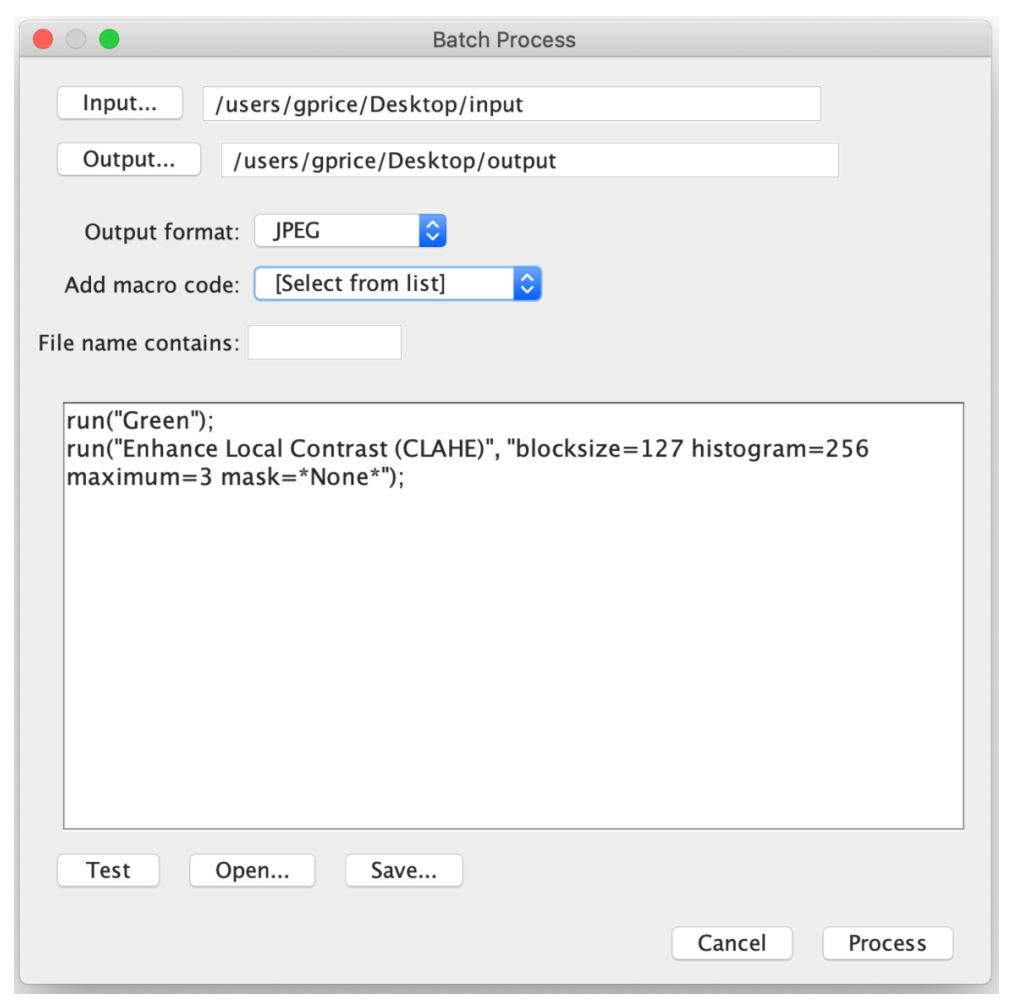

Figure 3. The Batch Process window. The 'Batch Process' window allows the use of a macro to apply changes to all images in the input folder, converting them to a JPEG, and saving in an output folder. Here, the colour lookup table is changed to "Green", and local contrast is enhanced using default settings.

B. Image analysis

1. Open an image (from the output folder selected above) by clicking 'File', 'Open'. Multiple images can be opened simultaneously.

2. In the toolbar, click 'Analyze', 'Tools', and 'ROI Manager'. A box will appear (Figure 4A).

3. From the main Fiji program, select an oval selection tool (Figure 4B).

4. Draw regions of interest (ROI), around each cell in the image. Each time you draw an ROI, click 'Add [t]' on the ROI Manager (or press 't' on your keyboard). Ticking 'Show All' helps to identify already selected cells.

5. After all cells have been selected (Figure 4C), draw a final ROI in a background area where cells are not present. Add this ROI to the ROI Manager.

6. In the toolbar, click 'Analyze', and 'Set Measurements'. A box will appear (Figure 4D). Untick all except for Integrated Density.

7. In the ROI Manager, click 'Measure'. A results box will appear with the intensity values for each $\mathrm{ROI}$ (Figure 4E). Copy this to Excel and subtract the last value (the background ROI). 
A

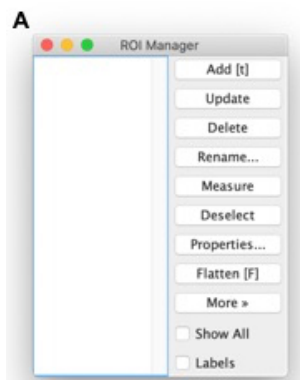

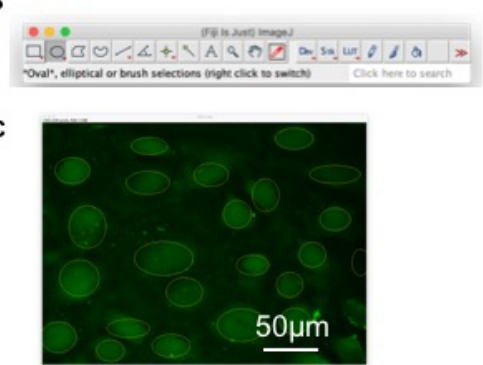

D

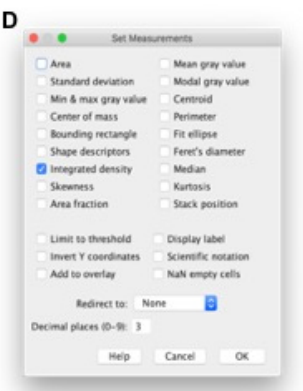

E

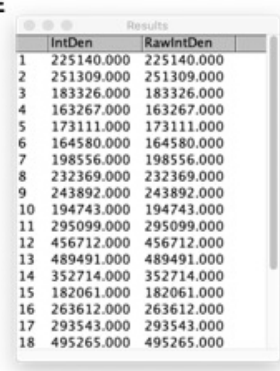

Figure 4. Adding regions of interest allows the measurement of fluorescence intensity. A. The Region of Interest (ROI) manager, which keeps track of all ROI added to the image. Once a selection is drawn on the image, click 'Add [t]' to add the ROI to the manager. B. An oval selection tool is selected. C. ROI around each cell have been drawn and added to the ROI Manager. A ROI of the background has also been added (right hand side) which will be subtracted from each cell. D. Select 'Integrated density' from the list of measurements. E. Once 'Measure' in Figure 4A has been clicked, a box of raw intensities will appear for further analysis.

8. Average the values, omitting any clearly anomalous intensities, and repeat this section for all images and treatments. Between each image, select all ROI in the ROI Manager and click 'Delete'.

9. Once all images have been analysed, an ANOVA/t-Test can be used to determine statistical significance, with typical results represented in Figure 5.

A
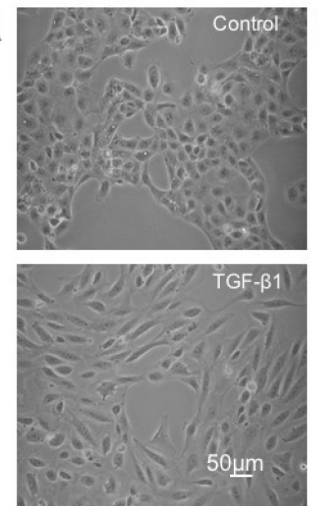

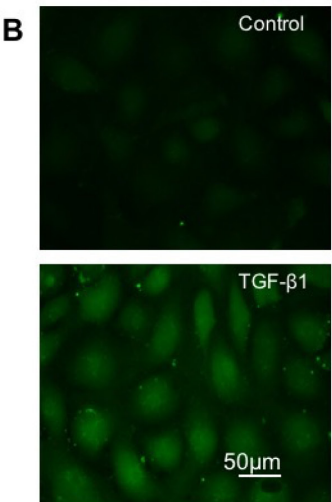

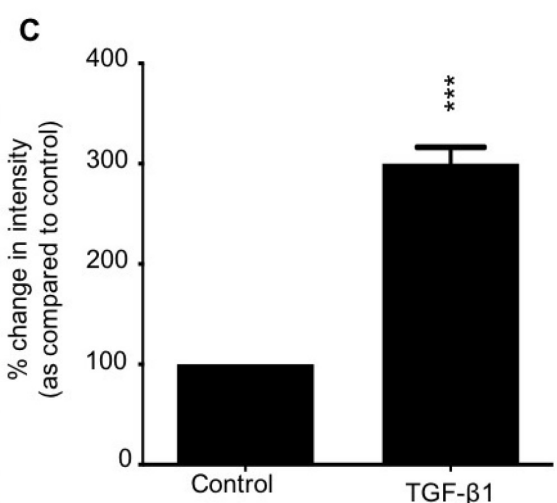

Figure 5. Example result using phase contrast microscopy and fluorescent images of control vs TGF $\beta 1$-treated HK-2 cells. Representative images of HK-2 cells treated with TGF$\beta 1$ as compared to control both under phase contrast (magnification $\times 20$ ) and fluorescence (magnification $\times 63)$ microscopy. A. TGF- $\beta 1(10 \mathrm{ng} / \mathrm{ml})$ stimulates a shift in HK-2 cell morphology from a classic cobblestone appearance (upper panel) to a more elongated fibroblast-like phenotype (lower panel). B. Under fluorescence microscopy, HK-2 cells exposed to TGF- $\beta 1$ exhibit increased dye uptake, as compared to control; C. TGF- $\beta 1(10 \mathrm{ng} / \mathrm{ml})$ treated cells demonstrate a $300 \%$ increase in dye uptake compared to control cells. Data is presented as 
mean \pm SEM with intensity expressed as a percentage change compared to low glucose control and representative of multiple cell recordings from 3 separate experiments. ( ${ }^{* * *}, P<0.001$ ).

\section{Notes}

1. This seeding density is optimised for HK-2 cells for a 48-h treatment and may differ for other cell lines/treatment periods.

2. Carboxyfluorescein concentration $(200 \mu \mathrm{M})$, incubation durations and washes have been optimised for HK-2 cells. For other cell lines these parameters may vary and will have to be optimised.

3. Aliquot $50 \mathrm{ml}$ of each balanced salt solution prior to adding 5(6)-carboxyfluorescein. Carefully weigh out $3.95 \mathrm{mg} 5(6)$-carboxyfluorescein and gently tip this into the balanced salt solution with the aid of a Pasteur pipette to ensure all 5(6)-carboxyfluorescein is mixed.

4. If the fluorescent light does not emit from the microscope, try pressing 'local' on the Lambda 102 optical filter changer. If this does not work, press 'reset' and ensure 'shutter A- ON' and 'shutter B - ON' are displayed on the Lambda unit.

5. A small number of hemichannels may be open without the removal of $\left[\mathrm{Ca}^{2+}\right] \mathrm{e}$.

6. Leaving $1 \mathrm{ml} 1 \times$ calcium-containing solution in the fluorodish will encourage permanent hemichannel closure, whilst preventing cell shrinkage and ultimate cell death.

7. To ensure captured light is emitted at $510 \mathrm{~nm}$, on the inverted microscope, make sure ' $F \mathrm{~s} 09$ ' is open.

8. TGF- $\beta 1$ treated HK-2 cells give an exposure time of $\sim 200-400 \mathrm{~ms}$.

9. In the process of image capture, prevent any unwanted noise/vibrations to preserve image quality ahead of data analysis.

10. During the localisation of a cell population, a high background may be present. Increase image quality/reduce background noise by further washing cells with $20 \mathrm{ml} 1 \times$ calcium-containing balanced salt solution.

11. Refer to online documentation for other available commands. Using the 'Plugins', 'Macros', 'Recorder' functions can also be useful to map changes made to an image to the macro equivalent.

\section{$\underline{\text { Recipes }}$}

1. Growth culture medium

$500 \mathrm{ml}$ Dulbecco's Modified Eagle Medium/Ham's F-12 nutrient mixture + Glutamine (2 mM) (DMEM/F-12)

$50 \mathrm{ml}$ foetal calf serum (10\% wt/vol)

$10 \mathrm{ml}$ Penicillin (100 IU/ml)-streptomycin $(100 \mu \mathrm{g} / \mathrm{ml})$

$1 \mu$ l epidermal growth factor $(5 \mathrm{ng} / \mathrm{ml})$ 
Stored at $4{ }^{\circ} \mathrm{C}$, pre-warm to $37^{\circ} \mathrm{C}$ prior to use

2. Low $(5 \mathrm{mM})$ glucose medium (1:1 ratio)

a. $500 \mathrm{ml}$ DMEM $(50 \mathrm{ml}$ foetal calf serum $(10 \% \mathrm{wt} / \mathrm{vol}), 10 \mathrm{ml}$ penicillin $(100 \mathrm{lU} / \mathrm{ml})-$ streptomycin $(100 \mu \mathrm{g} / \mathrm{ml})$ and $1 \mu \mathrm{l}$ epidermal growth factor $(5 \mathrm{ng} / \mathrm{ml})$

b. $500 \mathrm{ml} \mathrm{F}-12+$ GlutaMAX (10 mM glucose) $(50 \mathrm{ml}$ foetal calf serum ( $10 \% \mathrm{wt} / \mathrm{vol}), 10 \mathrm{ml}$ penicillin (100 lU/ml)-streptomycin $(100 \mu \mathrm{g} / \mathrm{ml})$ and $1 \mu \mathrm{l}$ epidermal growth factor $(5 \mathrm{ng} / \mathrm{ml})$

On the day, mix each medium in a 1:1 ratio to a desired volume in a sterilised atmosphere. Stored at $4{ }^{\circ} \mathrm{C}$, pre-warm to $37^{\circ} \mathrm{C}$ prior to use.

3. Low $(5 \mathrm{mM})$ glucose serum free medium (1:1 ratio)

a. $500 \mathrm{ml}$ DMEM $(10 \mathrm{ml}$ penicillin $(100 \mathrm{lU} / \mathrm{ml})$-streptomycin $(100 \mu \mathrm{g} / \mathrm{ml})$ and $1 \mu \mathrm{l}$ epidermal growth factor $(5 \mathrm{ng} / \mathrm{ml}))$

b. $500 \mathrm{ml} \mathrm{F}-12+$ GlutaMAX (10 mM glucose) $[10 \mathrm{ml}$ penicillin (100 lU/ml)-streptomycin (100 $\mu \mathrm{g} / \mathrm{ml})$ and $1 \mu \mathrm{l}$ epidermal growth factor $(5 \mathrm{ng} / \mathrm{ml})$

On the day, mix each medium in a 1:1 ratio to a desired volume in a sterilised atmosphere. Stored at $4{ }^{\circ} \mathrm{C}$, pre-warm to $37^{\circ} \mathrm{C}$ prior to use.

4. 5(6)-Carboxyfluorescein $(200 \mu \mathrm{M})$

$3.95 \mathrm{mg} 5(6)$-carboxyfluorescein

Add $50 \mathrm{ml}$ of $1 \times$ calcium-containing balanced salt solution or $1 \times$ calcium-free balanced salt solution. Sonicate at $44 \mathrm{kHz}$ for $10-20 \mathrm{~min}$ at $37^{\circ} \mathrm{C}$ until completely dissolved.

5. $1 \times$ Calcium-containing balanced salt solution $(1 \mathrm{~L}, \mathrm{pH} 7.4)$

$8.0 \mathrm{~g}$ of Sodium chloride ( $\mathrm{NaCl}, 137 \mathrm{mM})$

$0.4 \mathrm{~g}$ of Potassium chloride $(\mathrm{KCl}, 5.36 \mathrm{mM})$

$0.2 \mathrm{~g}$ of Magnesium sulphate heptahydrate $\left(\mathrm{MgSO}_{4} \cdot 7 \mathrm{H}_{2} \mathrm{O}, 0.81 \mathrm{mM}\right)$

$0.06 \mathrm{~g}$ of Sodium phosphate dibasic dihydrate $\left(\mathrm{Na}_{2} \mathrm{HPO}_{4} \cdot 2 \mathrm{H}_{2} \mathrm{O}, 0.34 \mathrm{mM}\right)$

$0.06 \mathrm{~g}$ of Potassium dihydrogen phosphate $\left(\mathrm{KH}_{2} \mathrm{PO}_{4}, 0.44 \mathrm{mM}\right)$

$0.35 \mathrm{~g}$ of Sodium bicarbonate $\left(\mathrm{NaHCO}_{3}, 4.17 \mathrm{mM}\right)$

$2.38 \mathrm{~g}$ of HEPES (4-(2-hydroxyethyl)-1-piperazineethanesulfonic acid, $10 \mathrm{mM}$ )

$0.19 \mathrm{~g}$ of Calcium chloride dihydrate $\left(\mathrm{CaCl}_{2} \cdot 2 \mathrm{H}_{2} \mathrm{O}, 1.26 \mathrm{mM}\right)$

$0.36 \mathrm{~g}$ of D-glucose $\left(\mathrm{C}_{6} \mathrm{H}_{12} \mathrm{O}_{6}, 2.02 \mathrm{mM}\right)$

Make up to $1 \mathrm{~L}$ using $\mathrm{dH}_{2} \mathrm{O}$ and adjust $\mathrm{pH}$ to 7.4 using $1 \mathrm{M}$ sodium hydroxide $(\mathrm{NaOH})$ or hydrochloric acid $(\mathrm{HCl})$. Store at $4{ }^{\circ} \mathrm{C}$ until needed and heat at $37^{\circ} \mathrm{C}$.

This can be made up as a $10 \times$ stock without the addition of calcium chloride dihydrate and glucose and kept in the fridge for long term. On the day of use, make up $1 \mathrm{~L}$ by diluting the $10 \times$ stock $1: 10$ with $\mathrm{dH}_{2} \mathrm{O}$, add $0.19 \mathrm{~g}$ calcium chloride dihydrate and $0.36 \mathrm{~g}$ of D-glucose to the $1 \mathrm{~L}$ $1 \times$ balanced salt solution and pre-warm to $37^{\circ} \mathrm{C}$ prior to use.

6. $1 \times$ Calcium-free balanced salt solution ( $1 \mathrm{~L}, \mathrm{pH} 7.4)$

$8.64 \mathrm{~g}$ of Sodium chloride $(\mathrm{NaCl}, 137 \mathrm{mM})$

$0.4 \mathrm{~g}$ of Potassium chloride $(\mathrm{KCl}, 5.36 \mathrm{mM})$

$0.2 \mathrm{~g}$ of Magnesium sulphate heptahydrate $\left(\mathrm{MgSO}_{4} \cdot 7 \mathrm{H}_{2} \mathrm{O}, 0.81 \mathrm{mM}\right)$ 
$0.06 \mathrm{~g}$ of Sodium phosphate dibasic dihydrate $\left(\mathrm{Na}_{2} \mathrm{HPO}_{4} \cdot 2 \mathrm{H}_{2} \mathrm{O}, 0.34 \mathrm{mM}\right)$

$0.06 \mathrm{~g}$ of Potassium dihydrogen phosphate $\left(\mathrm{KH}_{2} \mathrm{PO}_{4}, 0.44 \mathrm{mM}\right)$

$0.35 \mathrm{~g}$ of Sodium bicarbonate $\left(\mathrm{NaHCO}_{3}, 4.17 \mathrm{mM}\right)$

$2.38 \mathrm{~g}$ of HEPES (4-(2-hydroxyethyl)-1-piperazineethanesulfonic acid, $10 \mathrm{mM}$ )

$0.36 \mathrm{~g}$ of D-glucose $\left(\mathrm{C}_{6} \mathrm{H}_{12} \mathrm{O}_{6}, 2.02 \mathrm{mM}\right)$

$0.038 \mathrm{~g}$ EGTA (ethylene glycol-bis( $\beta$-aminoethyl ether)-N,N,N',N'-tetraacetic acid, $100 \mu \mathrm{M}$ )

Make up to $1 \mathrm{~L}$ using $\mathrm{ddH}_{2} \mathrm{O}$ and adjust $\mathrm{pH}$ to 7.4 using $1 \mathrm{M}$ sodium hydroxide $(\mathrm{NaOH})$ or hydrochloric acid $(\mathrm{HCl})$. Store at $4{ }^{\circ} \mathrm{C}$ until needed and heat at $37^{\circ} \mathrm{C}$.

This can be made up as a 10x stock without the addition of EGTA and glucose and kept in the fridge for long term. On the day of use, make up $1 \mathrm{~L}$ by dilute the $10 \times$ stock $1: 10$ with $\operatorname{dd~}_{2} \mathrm{O}$, add $0.038 \mathrm{~g}$ EGTA and $0.36 \mathrm{~g}$ of D-glucose to the $1 \mathrm{~L} 1 \times$ balanced salt solution and pre-warm to $37^{\circ} \mathrm{C}$ prior to use.

\section{Acknowledgments}

CEH and PES would like to acknowledge the generous support of Diabetes UK (16/0005427 16/005544 and 18/0005919).

\section{Competing interests}

The authors declare that they have no competing interests.

\section{$\underline{\text { References }}$}

1. Bosco, D., Haefliger, J. A. and Meda, P. (2011). Connexins: key mediators of endocrine function. Physiol Rev 91(4): 1393-1445.

2. Brokamp, C., Todd, J., Montemagno, C. and Wendell, D. (2012). Electrophysiology of single and aggregate Cx43 hemichannels. PLoS One 7(10): e47775.

3. Cea, L. A., Fernandez, G., Arias-Bravo, G., Castillo-Ruiz, M., Escamilla, R., Branes, M. C. and Saez, J. C. (2020). Blockade of Hemichannels Normalizes the Differentiation Fate of Myoblasts and Features of Skeletal Muscles from Dysferlin-Deficient Mice. Int J Mol Sci 21(17): 6025.

4. Ceelen, L., Haesebrouck, F., Vanhaecke, T., Rogiers, V. and Vinken, M. (2011). Modulation of connexin signaling by bacterial pathogens and their toxins. Cell Mol Life Sci 68(18): 3047-3064.

5. Hills, C., Price, G. W., Wall, M. J., Kaufmann, T. J., Chi-Wai Tang, S., Yiu, W. H. and Squires, P. E. (2018). Transforming Growth Factor Beta 1 Drives a Switch in Connexin Mediated Cellto-Cell Communication in Tubular Cells of the Diabetic Kidney. Cell Physiol Biochem 45(6): 2369-2388.

6. Johnson, R. G., Le, H. C., Evenson, K., Loberg, S. W., Myslajek, T. M., Prabhu, A., Manley, A. M., O'Shea, C., Grunenwald, H., Haddican, M., Fitzgerald, P. M., Robinson, T., Cisterna, B. A., 
Saez, J. C., Liu, T. F., Laird, D. W. and Sheridan, J. D. (2016). Connexin Hemichannels: Methods for Dye Uptake and Leakage. J Membr Biol 249(6): 713-741.

7. Lopez, W., Ramachandran, J., Alsamarah, A., Luo, Y., Harris, A. L. and Contreras, J. E. (2016). Mechanism of gating by calcium in connexin hemichannels. Proc Natl Acad Sci U S A 113(49): E7986-E7995.

8. Musil, L. S. and Goodenough, D. A. (1991). Biochemical analysis of connexin43 intracellular transport, phosphorylation, and assembly into gap junctional plaques. J Cell Biol 115(5): 13571374.

9. Pinto, B. I., Pupo, A., Garcia, I. E., Mena-Ulecia, K., Martinez, A. D., Latorre, R. and Gonzalez, C. (2017). Calcium binding and voltage gating in Cx46 hemichannels. Sci Rep 7(1): 15851.

10. Price, G. W., Chadjichristos, C. E., Kavvadas, P., Tang, S. C. W., Yiu, W. H., Green, C. R., Potter, J. A., Siamantouras, E., Squires, P. E. and Hills, C. E. (2020). Blocking Connexin-43 mediated hemichannel activity protects against early tubular injury in experimental chronic kidney disease. Cell Commun Signal 18(1): 79.

11. Roy, S., Jiang, J. X., Li, A. F. and Kim, D. (2017). Connexin channel and its role in diabetic retinopathy. Prog Retin Eye Res 61: 35-59.

12. Sáez, J. C., Contreras-Duarte, S., Labra, V. C., Santibanez, C. A., Mellado, L. A., Inostroza, C. A., Alvear, T. F., Retamal, M. A., Velarde, V. and Orellana, J. A. (2020). Interferon-y and high glucose-induced opening of $\mathrm{Cx} 43$ hemichannels causes endothelial cell dysfunction and damage. Biochim Biophys Acta Mol Cell Res 1867(8): 118720.

13. Sáez, J. C. and Green, C. (2018). Involvement of Connexin Hemichannels in the Inflammatory Response of Chronic Diseases. Int J Mol Sci 19(9): 2469.

14. Siamantouras, E., Price, G. W., Potter, J. A., Hills, C. E. and Squires, P. E. (2019). Purinergic receptor (P2X7) activation reduces cell-cell adhesion between tubular epithelial cells of the proximal kidney. Nanomedicine 22: 102108.

15. Solini, A., Usuelli, V. and Fiorina, P. (2015). The dark side of extracellular ATP in kidney diseases. J Am Soc Nephrol 26(5): 1007-1016.

16. Spray, D. C. and Hanani, M. (2019). Gap junctions, pannexins and pain. Neurosci Lett 695: 4652.

17. Taruno, A. (2018). ATP Release Channels. Int J Mol Sci 19(3): 808.

18. Trexler, E. B., Bukauskas, F. F., Bennett, M. V., Bargiello, T. A. and Verselis, V. K. (1999). Rapid and direct effects of $\mathrm{pH}$ on connexins revealed by the connexin46 hemichannel preparation. $J$ Gen Physiol 113(5): 721-742.

19. Veenstra, R. D. (2001). Voltage clamp limitations of dual whole-cell gap junction current and voltage records. I. Conductance measurements. Biophys J 80(5): 2231-2247. 